\title{
Oral hairy leukoplakia arising in a patient with hairy cell leukaemia: the first reported case
}

\author{
Gemma Davis, ${ }^{1}$ Alexandra Perks, ${ }^{1}$ Pemith Liyanage, ${ }^{2}$ Konrad Staines ${ }^{1}$
}

${ }^{1}$ Oral Medicine, University of Bristol Dental Hospital, Bristol, UK

${ }^{2}$ Oral and Maxillofacial Pathology, University of Bristol Dental Hospital, Bristol, UK

\section{Correspondence to} Gemma Davis, gld645@ googlemail.com

Accepted 23 March 2017

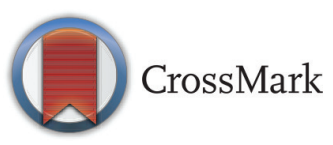

To cite: Davis G, Perks A Liyanage $P$, et al. BMJ Case Rep Published Online First: [please include Day Month Year]. doi:10.1136/bcr-2016 218663

\section{SUMMARY}

Oral hairy leukoplakia $(\mathrm{OHL})$ is an oral mucosal lesion that is associated with Epstein-Barr virus infection. It commonly presents as an asymptomatic, nonremovable white patch on the lateral borders of the tongue in individuals who are immunocompromised. Historically, OHL was thought to be pathognomonic of HIV infection; however, it is now an established phenomenon in a range of conditions affecting immune competence. Hairy cell leukaemia (HCL) is a rare chronic $B$ cell lymphoproliferative disease named after the distinctive cytology of the atypical cells. We report the first case of $\mathrm{OHL}$ arising in an individual with $\mathrm{HCL}$ that resolved following remission of the haematological malignancy.

\section{BACKGROUND}

Oral hairy leukoplakia (OHL) is an oral mucosal lesion associated with infection and replication of the Epstein-Barr virus (EBV). ${ }^{1}$ OHL was first described in 1984 and has largely been reported as an HIV-associated and AIDS-associated condition. $^{2-4}$ It has, however, also been described in HIV-negative immunocompromised individuals, such as transplant recipients secondary to immunosuppressant medication, patients with haematological malignancies, and more recently in those using inhaled steroids and anticonvulsants. ${ }^{5-8}$ Therefore $\mathrm{OHL}$ is now best regarded as a marker of immunosuppression rather than being pathognomonic of HIV infection.

The characteristic clinical presentation of OHL is that of an asymptomatic, non-removable white patch with a corrugated surface typically involving the lateral and dorsolateral surfaces of the tongue bilaterally. It less commonly occurs in other oral sites such as the buccal mucosa and gingivae. ${ }^{9}$ The most common histopathological features of OHL include hyperparakeratosis, epithelial hyperplasia, koilocyte-like cells within the prickle cell layer and minimal or complete absence of inflammatory cells in the lamina propria even with the presence of candida on the surface. A band-like layer of cells with clear cytoplasm can also be seen in the upper spinous layer. ${ }^{910}$ These features are not exclusive to OHL, and therefore EBV demonstration in lesional tissue is required for definitive diagnosis. ${ }^{11}{ }^{12}$ Various techniques have been described for the detection of EBV in tissue sections, including in situ hybridisation (ISH), PCR and immunohistochemistry. ${ }^{13-15}$ Due to the abundant expression of EBV-encoded RNA (EBER1 and EBER2) in latently infected cells, EBER is a suitable molecular target for detecting the presence of EBV. Therefore EBER ISH is considered to be the gold standard. ${ }^{111216}$

Here we describe a case of OHL in association with hairy cell leukaemia (HCL). HCL is a rare chronic B cell lymphoproliferative disease characterised by splenomegaly, pancytopenia and infiltration of leukaemic cells into the liver, spleen and bone marrow. ${ }^{16}$ HCL derives its name from the distinctive cytology of the atypical cells, which demonstrate surface hair-like projections and membrane ruffles identified in the blood and/ or bone marrow. ${ }^{17}$ Identification of these clinical and morphological features along with identification of a V600E mutation in the BRAF gene, which has been shown to be a reliable molecular marker, is used for diagnosis. ${ }^{18}$ After a literature search of PubMed and Medline, this is the first time that OHL associated with HCL has been reported in the literature.

\section{CASE PRESENTATION}

A 48-year-old male was referred to the Oral Medicine Department at Bristol Dental Hospital for assessment of an asymptomatic white patch of 6 months' duration on the right lateral border of his tongue. On initial presentation, there was no significant medical history and the patient was a never-smoker. Extraoral examination of the head and neck was unremarkable, with no evidence of lymphadenopathy. Intraoral examination revealed a relatively extensive soft, slightly raised, corrugated white patch localised to the right lateral border of the tongue (figure 1).

There was some slight sharpness of the cusps of the lower molar teeth bilaterally, which were thought to be contributing to this lesion. A clinical working diagnosis of frictional keratosis was made, with OHL as a differential. The patient returned to his general dentist for the fabrication of a lower polythene occlusal cover and smoothing of the lower molar cusps, and a review appointment was made 3 months later.

At this follow-up appointment, there had been no change in the appearance of this lesion. There had, however, been a significant change in his medical history. A routine full blood count had been undertaken by his general medical practitioner which identified both neutropaenia $\left(1.07 \times 10^{9}\right)$ and thrombocytopaenia $\left(75 \times 10^{9}\right)$. An urgent referral to haematology followed where bone marrow 


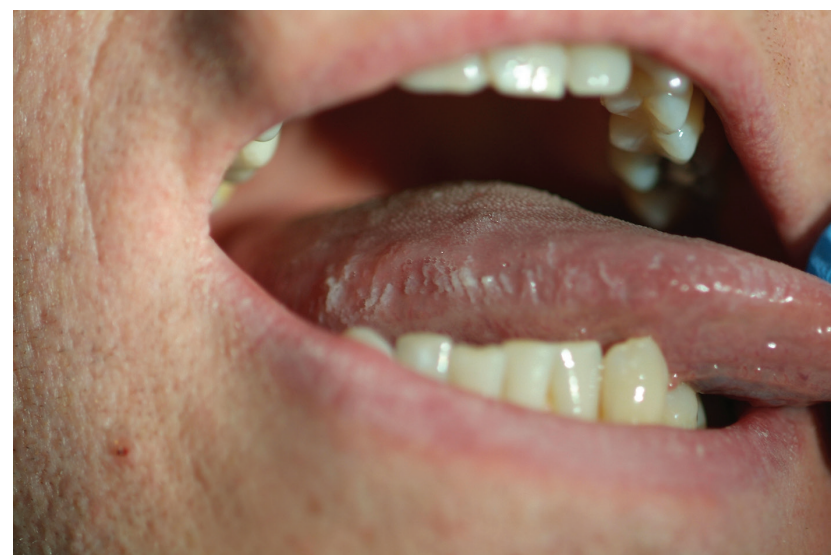

Figure 1 Corrugated white patch on the right lateral border of the tongue.

aspirate and trephine biopsy were undertaken, which showed a diffuse infiltrate of medium-sized lymphoid cells with cytoplasmic projections. Molecular analysis of DNA from the bone marrow aspirate also tested positive for the BRAF Val600Glu mutation. These features were all consistent with a diagnosis of HCL.

As a result of this change in medical history, our working diagnosis changed from frictional keratosis to OHL presenting secondary to HCL-related immunosuppression. After liaising with haematology, an incisional biopsy of the lesion was performed with prophylactic antibiotic cover. The patient had a reported penicillin allergy; therefore, it was agreed that clindamycin $600 \mathrm{mg}$ given 1 hour preoperatively followed by $300 \mathrm{mg}$ three times a day for 7 days was the most appropriate. Local measures of cautery and primary wound closure were adopted.

The histopathology revealed mucosa comprising parakeratinised and acanthotic stratified squamous epithelium with surface corrugation. A band of vacuolated cells was seen just beneath the parakeratin layer, and the superficial lamina propria was devoid of any inflammatory cells (figure 2). Periodic acidSchiff stain revealed the presence of candidal hyphae. EBER ISH was performed and showed numerous positive cells, confirming EBV-related pathology (figure 3). A clinicopathological diagnosis of OHL was made.

His HCL was treated with purine analogue therapy and complete morphological remission was achieved. Three months

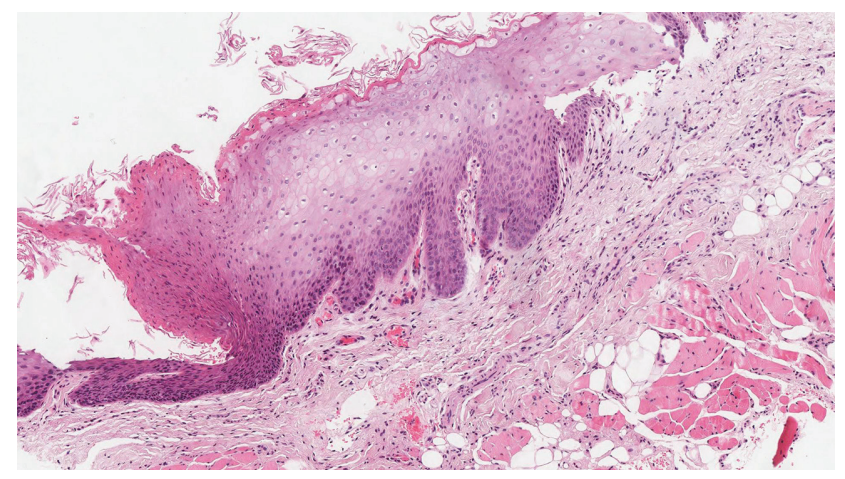

Figure 2 H\&E stained section (x10). Epithelium showing hyperparakeratosis, acanthosis and a band of vacuolated cell. No significant inflammatory cell infiltrate is seen in the underlying lamina propria.

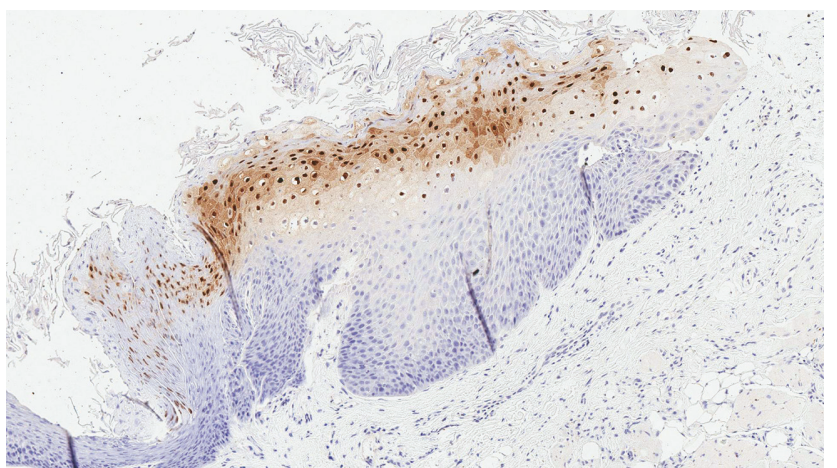

Figure 3 In situ hybridisation with EBER probe shows numerous positive cells in the prickle cell layer. EBER, Epstein-Barr virus-encoded RNA.

after completion of HCL treatment, the OHL lesion on the right lateral border of the tongue had resolved. He is now under the routine care of his general dental practitioner for twice yearly review. The lesion has not reoccurred.

\section{DISCUSSION}

$\mathrm{OHL}$ is a benign EBV-associated lesion that most commonly presents as an asymptomatic, corrugated white patch on the lateral borders of the tongue. ${ }^{9}$ It is a well-documented phenomenon associated with immunodeficiency, but more recently has been reported in apparent immunocompetent individuals such as those using long-term inhaled steroids. Despite this being the first case of OHL associated with HCL in the literature, OHL has been readily described in association with other haematological malignancies. In 2010, Cho et al described a similar case of OHL presenting as the initial sign of acute myeloid leukaemia in a 15 -year-old boy. ${ }^{19}$ It has also been described in individuals with multiple myeloma and acute lymphocytic leukaemia. ${ }^{6} 20$

EBV, otherwise known as human herpes virus 4, is known to infect over $95 \%$ of the world's adult population. ${ }^{21}$ Primary infection activates the innate and adaptive immune systems, and the virus remains latent lifelong by living in memory B lymphocytes. $^{22-24}$ It is primarily transmitted through saliva as infected cells are shed into the oral cavity. Despite the clearly established link between EBV and OHL, its exact role is still unclear. ${ }^{22} 24$ Debate remains as to whether OHL arises as a result of reactivation of latent strains within the tongue epithelium or as a result of repeated direct infection from EBV within the saliva. ${ }^{23}$ It has been postulated that the development of OHL occurring on the lateral borders of the tongue may be due to the resting position of the tongue in a pool of EBV-infected saliva in the floor of the mouth. ${ }^{23}$

In this case, a provisional clinical diagnosis of frictional keratosis was made due to the absence of relevant medical history. Frictional keratosis is a frequently occurring lesion that commonly presents on the lateral borders of the tongue. Certain histological features are shared with OHL, such as a corrugated hyperkeratotic surface epithelium, epithelial hyperplasia and occasional koilocyte-like cells resulting from intracellular oedema and compressed nuclei. ${ }^{23}$ Because of this, EBV detection within the lesional tissue is required for definitive diagnosis. ${ }^{11}$ However, suspicion of OHL may be raised for the reporting pathologist before the outcome of the EBER ISH due to the presence of perinuclear chromatin clumping within viral infected balloon cells. 
Learning points

- Oral hairy leukoplakia (OHL) is a disease entity that is no longer exclusive to patients with HIV and is now recognised as a marker of immunosuppression.

- The detection of Epstein-Barr virus within the lesional tissue is required for definitive diagnosis due to shared clinical and histological features with other commonly occurring oral lesions such as frictional keratosis.

- OHL does not often require treatment and will spontaneously resolve upon establishment of immune competence.

Contributors GD: literature search, drafted the manuscript and final approval of completed article. AP: contributed to the manuscript. PL: contributed histopathological information and involved in manuscript editing. KS: Evaluation and editing of manuscript to be published.

Competing interests None declared.

Patient consent Obtained.

Provenance and peer review Not commissioned; externally peer reviewed.

(c) BMJ Publishing Group Ltd (unless otherwise stated in the text of the article) 2017. All rights reserved. No commercial use is permitted unless otherwise expressly granted.

\section{REFERENCES}

1 Slots J, Saygun I, Sabeti M, et al. Epstein-Barr virus in oral diseases. J Periodontal Res 2006:41:235-44.

2 Greenspan D, Greenspan JS, Conant M, et al. Oral "hairy" leucoplakia in male homosexuals: evidence of association with both papillomavirus and a herpes-group virus. Lancet 1984;2:831-4.

3 Reichart PA, Langford A, Gelderblom HR, et al. Oral hairy leukoplakia: observations in 95 cases and review of the literature. J Oral Pathol Med 1989:18:410-5.

4 Nokta M. Oral manifestations associated with HIV infection. Curr HIVIAIDS Rep 2008;5:5-12.

5 Greenspan D, Greenspan JS, de Souza Y, et al. Oral hairy leukoplakia in an HIVnegative renal transplant recipient. J Oral Pathol Med 1989;18:32-4.

6 Blomgren J, Bäck H. Oral hairy leukoplakia in a patient with multiple myeloma. Oral Surg Oral Med Oral Pathol Oral Radiol Endod 1996;82:408-10.
7 Chambers AE, Conn B, Pemberton M, et al. Twenty-first-century oral hairy leukoplakia--a non-HIV-associated entity. Oral Surg Oral Med Oral Pathol Oral Radiol 2015;119:326-32.

8 Gordins P, Sloan P, Spickett GP, et al. Oral hairy leukoplakia in a patient on long-term anticonvulsant treatment with lamotrigine. Oral Surg Oral Med Oral Pathol Oral Radiol 2011:111:e17-e23.

9 Braz-Silva PH, de Rezende NP, Ortega KL, et al. Detection of the Epstein-Barr virus (EBV) by in situ hybridization as definitive diagnosis of hairy leukoplakia. Head Neck Pathol 2008;2:19-24.

10 Triantos D, Porter SR, Scully C, et al. Oral hairy leukoplakia: clinicopathologic features, pathogenesis, diagnosis, and clinical significance. Clin Infect Dis 1997;25:1392-6.

11 EC-Clearinghouse on oral problems related to HIV infection and WHO collaborating centre on oral manifestations of the immunodeficiency virus. J Oral Pathol Med 1993;22:289-91.

12 Greenspan JS, Barr CE, Sciubba JJ, et al. Oral manifestations of HIV infection. definitions, diagnostic criteria, and principles of therapy. The U.S.A. oral AIDS collaborative group. Oral Surg Oral Med Oral Pathol 1992;73:142-4.

13 Mabruk MJ, Flint SR, Toner M, et al. In situ hybridization and the polymerase chain reaction (PCR) in the analysis of biopsies and exfoliative cytology specimens for definitive diagnosis of oral hairy leukoplakia (OHL). J Oral Pathol Med 1994:23:302-8.

14 Felix DH, Jalal H, Cubie HA, et al. Detection of Epstein-Barr virus and human papillomavirus type 16 DNA in hairy leukoplakia by in situ hybridisation and the polymerase chain reaction. J Oral Pathol Med 1993;22:277-81.

15 Gulley ML. Molecular diagnosis of Epstein-Barr virus-related diseases. J Mol Diagn 2001;3:1-10.

16 Swords R, Giles F. Hairy cell leukemia. Med Oncol 2007;24:7-15.

17 Salam L, Abdel-Wahab 0. Hairy cell leukemia: update and current therapeutic approach. Curr Opin Hematol 2015;22:355-61.

18 Arcaini L, Zibellini S, Boveri E, et al. The BRAF V600E mutation in hairy cell leukemia and other mature B-cell neoplasms. Blood 2012;119:188-91.

$19 \mathrm{Cho} \mathrm{HH}$, Kim SH, Seo SH, et al. Oral hairy leukoplakia which occurred as a presenting sign of acute myeloid leukemia in a child. Ann Dermatol 2010;22:73-6.

20 Nicolatou 0 , Nikolatos G, Fisfis M, et al. Oral hairy leukoplakia in a patient with acute lymphocytic leukemia. Oral Dis 1999;5:76-9.

21 Hall LD, Eminger LA, Hesterman KS, et al. Epstein-Barr virus: dermatologic associations and implications: part I. mucocutaneous manifestations of Epstein-Barr virus and nonmalignant disorders. J Am Acad Dermatol 2015;72:1-19.

22 Hislop AD, Taylor GS, Sauce D, et al. Cellular responses to viral infection in humans: lessons from Epstein-Barr virus. Annu Rev Immunol 2007;25:587-617.

23 Piperi E, Omlie J, Koutlas IG, et al. Oral hairy leukoplakia in HIV-negative patients: report of 10 cases. Int J Surg Pathol 2010;18:177-83.

24 Greenspan JS, Greenspan D, Webster-Cyriaque J, et al. Webster-Cyriaque. hairy leukoplakia; lessons learned: 30-plus years. Oral Dis 2016;22(S1):120-7.

Copyright 2017 BMJ Publishing Group. All rights reserved. For permission to reuse any of this content visit

http://group.bmj.com/group/rights-licensing/permissions.

BMJ Case Report Fellows may re-use this article for personal use and teaching without any further permission.

Become a Fellow of BMJ Case Reports today and you can:

- Submit as many cases as you like

- Enjoy fast sympathetic peer review and rapid publication of accepted articles

- Access all the published articles

- Re-use any of the published material for personal use and teaching without further permission

For information on Institutional Fellowships contact consortiasales@bmjgroup.com

Visit casereports.bmj.com for more articles like this and to become a Fellow 